\title{
EFL CLASS FOR IRREGULAR MIGRANTS \\ IN EDUCATIONAL PROGRAM AT RUMAH \\ DETENSI IMIGRASI SEMARANG
}

\author{
M. Risya Islami \\ UIN Walisongo Semarang
}

\begin{abstract}
This research describes an EFL class for irregular migrants in educational program at Rumah Detensi Imigrasi. Irregular migrants are foreigners staying in Indonesia without any legal document or immigration permission. Rumah Detensi Imigrasi is a temporary shelter for irregular migrants during waiting periods for refugee status from UNHCR to come to a destination country like Australia, New Zaeland etc. EFL class is a class for irregular migrants at Rumah Detensi Imigrasi to learn English especially speaking and writing skills. The teaching learning process of the EFL class uses Grammar translation, Reading and communicative approaches. The materials delivered are vocabularies, grammar, speaking and writing skills. The class is aimed at providing students with language skills since most of the destinations are English speaking countries.
\end{abstract}

Keyword: EFL class, irregular migrants, teaching learning process, teaching approach, material delivered. 


\section{INTRODUCTION}

The 1951 United Nation (UN) Convention relating to the Status of Migrants states that migrants are people who are outside the country of their nationality or the place of their habitual residence, which have a well-founded fear of persecution because of race, religion, nationality, membership in a particular social group or political opinion (UNHCR, :21).

The activity of International community in handling migrant issue began in 1921 when League of Nations (LN) appointed Fridtj of Nansen, Norwegian and the explorer of continental Europe, as high commissioner for Russian migrant in Europe. After LN switched to United Nations (UN), UN established International Refugee Organization (IRO) with mandate to protect groups of migrants. At a later time, IRO switched to United Nations High Commissioner for Migrant (UNHCR) (Syam, 2015). With the increase of migrants problems in the late 1950s and early 1960s, the time and scope of the 1951 convention need to be extended. In its development, an additional protocol on UN Convention relating to the Status of Migrants of 1951 is designed and approved and called the 1967 protocol (Riyanto, 2014: 67).

Indonesia has not ratified the 1951 Convention and the 1967 Protocol. It means that Indonesia does not have an authority to give refugee status. Thus the authority of refugee status given by UNHCR in accordance with the UNHCR mandate of UNHCR statute of 1950. All countries including those that have not ratified the Migrant Convention must uphold migrant protection standards that have become part of international law (Krustiyati, 2012:171).

In 1992, Indonesian goverment, through immigration law, introduced Karantina Imigrasi as a temporary shelter for foreigners who imposed the act of expulsion or deportation or other immigration (Law No. 9 of 1992). Based on article 1 paragraph 16 Indonesian law number 9 of 1992, the expulsion or deportation means an action of driving foreigners out of Indonesian territory because of unwanted coming. In the following year, Karantina Imigrasi becomes the pioneer of Rumah Detensi Imigrasi (Rudenim).

Based on the decision of Ministry of Justice and Human 
Right number M.01.PR.07.04 of 2004 on organization and detention camp work, the minister turns Karantina Imigrasi into Rumah Detensi Imigrasi. Now there are Thirteen Rudenims in Indonesia (Indrayana, 2015). Rudenim is a temporary shelter for asylum seekers or migrants who come to Indonesia before being returned to their home land or taking to their destination country.

The detention center ini Semarng, namely Rumah Detensi Imigrasi (Rudenim), is located in Krapyak, West Semarang. Rudenim is under the authority of Central Java regional office of Ministry of Justice and Human Right and inhabited by 72 irregular migrants. The irregular migrants consist of men, women and children who came from Palestine, Iraq, Iran, Myanmar, Somalia, Syria, and Afghanistan. Consequently, they have different culture and language and they do not use English as the first language.

With cooperation of the International Organization for Migration (IOM), it provides logistical support and education for irregular migrants, The Indonesian government holds an English as foreign languange (EFL) class for irregular migrants during their stay in Rudenim Semarang. Therefore, the program is intended to make those irregular migrants able to socialize with local community easily on their arrival at the destination countries.

This article describes how teaching and learning in EFL class for irregular migrants in educational program at Rudenim Semarang is carried out and what material is delivered during the class.

\section{METHOD}

This research employs qualitative design. The subject of the research is irregular migrants in EFL class of educational program at Rumah Detensi Imigrasi Semarang. The number of irregular migrants is 72 people. They come from Palestine, Iraq, Myanmar, Somalia, Syria, Afghanistan, and Iran. They have been staying at Rudenim for seven to thirteen months. The teacher of EFL class are activists of PKBI Kota Semarang, located on Kalibanteng Kulon Semarang, named Ikfi and Novia. The class is conducted regularly on Monday and Wednesday. The data were collected through observation, interview, and documentation. 


\section{FINDINGS}

\subsection{Irregular Migrants at Rudenim}

The Indonesian law 6/ 2011 on Immigration states that foreigner means "Person that is non-Indonesian citizen". On Immigration law, each foreigner in Indonesian territory must have immigration permission. Those who do not have any immigration permission, they come as irregular migrants. The immigration permission refers to an entry permit, based on its purpose to Indonesia territory, and stay permission. Stay permission, based on Indonesian law 6/2011 on Immigration, is "permission that is given for foreigner by immigration stakeholder to stay in Indonesian territory".

The permission consists of permission of stop over, it is permission for foreigner that needs to drop in Indonesian territory to continue going to objective country; permission to visit, it is a permission for foreigner that visits to Indonesian territory in a short time for the task of government, tourism, social culture activity or for work; limited stay permission, it is a permission for foreigner in Indonesian territory in limited time; permanent stay permission, it is a permission for foreigner for permanent stay in Indonesian territory. In Immigration law, there are some requirements to get immigration permission such as holding a legitimate travel letter, owning a visa, being healthy, not suffering from mental disorder or infectious diseases endanger public health, holding reentry permit, having permission to come to other country, and giving the true information in getting travel letter or Visa (Syahriful, 1993:84).

An Educational program is a program conducted by Rumah Detensi Imigrasi and International organization for migration (IOM) for irregular migrants staying at Rudenim. There are three classes in Educational Program namely EFL class, creativity class for children, and handicraft class. EFL class is a class for irregular migrants to learn English. Creativity class for children is a class for children to express their creativity like singing, drawing, coloring, puzzling, and counting. Handicraft class is a class especially for girls to make some crafts by hand. EFL class is conducted on Monday and Wednesday, Creativity class is conducted on Tuesday and Thursday, and Handicraft class is on Friday. Here is the list of EFL 
EFL Class for Irregular Migrants

class particpants:

\begin{tabular}{|c|c|c|c|c|}
\hline NO & Name & Sex & Age & Nationality \\
\hline 1 & Namir Ahmad Muhammad & $\mathrm{M}$ & 49 & Palestine \\
\hline 2 & Randa Oemar Sharif & $\mathrm{F}$ & 44 & Palestine \\
\hline 3 & Shad Namir Ahmad & $\bar{F}$ & 21 & Palestine \\
\hline 4 & Muhammad Namir Ahmad & $\mathrm{M}$ & 19 & Palestine \\
\hline 5 & Hibatallah Namir Ahmad & $\mathrm{F}$ & 11 & Palestine \\
\hline 6 & Mousa Ismail Matar & $\mathrm{M}$ & 65 & Palestine \\
\hline 7 & Najah Salah & $\mathrm{F}$ & 59 & Palestine \\
\hline 8 & Mahmoud Mousa Ismail & $\mathrm{M}$ & 22 & Palestine \\
\hline 9 & Samir Jasim Muhammad & $\mathrm{M}$ & 34 & Iraq \\
\hline 10 & Hannan Mousa Ismail & $\mathrm{F}$ & 33 & Palestine \\
\hline 11 & Ahmed Samir Jasim & $\mathrm{M}$ & 9 & Iraq \\
\hline 12 & Sahra Samir Jasim & $\mathrm{F}$ & 5 & Iraq \\
\hline 13 & Saif Samir Jasim & $\mathrm{M}$ & 3 & Iraq \\
\hline 14 & Faroun Aljarian & $\bar{M}$ & 56 & Algeria \\
\hline 15 & Muhammad Nori & $\bar{M}$ & 39 & Iran \\
\hline 16 & Yasaman Orogirad & $\mathrm{F}$ & 28 & Iran \\
\hline 17 & Aynaz Nori Dashbelagh & $\mathrm{F}$ & 8 & Iran \\
\hline 18 & Muhammad Mehrab Nori & $\mathrm{M}$ & 7 & Iran \\
\hline 19 & Buti & $\mathrm{F}$ & 45 & Myanmar \\
\hline 20 & Gi Rahman & $\mathrm{M}$ & 7 & Myanmar \\
\hline 21 & Imam Hasan & $\mathrm{M}$ & 32 & Myanmar \\
\hline 22 & Aisyah & $\mathrm{F}$ & 7 & Myanmar \\
\hline 23 & Nobi Husien & $\mathrm{M}$ & 25 & Myanmar \\
\hline 24 & Hamid Husien & $\mathrm{M}$ & 5 & Myanmar \\
\hline 25 & Mohamad Nur Hussen & $\bar{M}$ & 40 & Myanmar \\
\hline 26 & Nur Muhammad & $\mathrm{M}$ & 55 & Myanmar \\
\hline 27 & Maryam & $\mathrm{F}$ & 38 & Myanmar \\
\hline 28 & Nur Nisah & $\mathrm{F}$ & 32 & Myanmar \\
\hline 29 & Nur Syaban & $\mathrm{F}$ & 11 & Myanmar \\
\hline 30 & Muhammad Yusuf & $\mathrm{M}$ & 10 & Myanmar \\
\hline 31 & Nur Aisyah & $\mathrm{F}$ & 9 & Myanmar \\
\hline 32 & Nurul Huda & $\mathrm{M}$ & 2 & Myanmar \\
\hline 33 & Nurul Khan & $\mathrm{M}$ & 26 & Myanmar \\
\hline 34 & Aisah & $\mathrm{F}$ & 23 & Myanmar \\
\hline 35 & Nuraina & $\mathrm{F}$ & 1 & Myanmar \\
\hline 36 & Mochammmad Shafie & $\mathrm{M}$ & 27 & Myanmar \\
\hline
\end{tabular}




\begin{tabular}{|c|l|c|c|c|}
\hline NO & \multicolumn{1}{|c|}{ Name } & Sex & Age & Nationality \\
\hline 37 & Nur Iza & F & 20 & Myanmar \\
\hline 38 & Nur Shakila & F & 3 & Myanmar \\
\hline 39 & Nur Sabrina & F & 2 & Myanmar \\
\hline 40 & Dil Muhammad & M & 45 & Myanmar \\
\hline 41 & Noor Nisa & F & 32 & Myanmar \\
\hline 42 & Halimah & F & 17 & Myanmar \\
\hline 43 & Anwar Shah & M & 5 & Myanmar \\
\hline 44 & Mohammad Shah & M & 5 & Myanmar \\
\hline 45 & Akbar Shah & M & 3 & Myanmar \\
\hline 46 & Noor Hasan & M & 34 & Myanmar \\
\hline 47 & Thi Dar Win & F & 26 & Myanmar \\
\hline 48 & Shwe Sin Oo & F & 6 & Myanmar \\
\hline 49 & Min Khan Kyaw & M & 2 & Myanmar \\
\hline 50 & Hla Oo & M & 24 & Myanmar \\
\hline 51 & Marwo Al Nuurani & F & 8 & Somalia \\
\hline 52 & Maryam Al Nuurani & F & 10 & Somalia \\
\hline 53 & Sheda Muhamad Abdullah & F & 40 & Somalia \\
\hline 54 & Abdi Kadir Ali Nuurani & M & 12 & Somalia \\
\hline 55 & Saif Ali Nekmah & M & 32 & Iraq \\
\hline 56 & Rim Ali & F & 30 & Iraq \\
\hline 57 & Yousef Saif & M & 8 & Iraq \\
\hline 58 & Abdullah Saif & M & 5 & Iraq \\
\hline 59 & Ehtear Salehuddin & M & 18 & Iraq \\
\hline 60 & Faiz Muhammad Ali & M & 36 & Iraq \\
\hline 61 & Gadah Muhammad Musa & F & 36 & Syria \\
\hline 62 & Tara Faiz Muhammad & F & 3 & Iraq \\
\hline 63 & Sallahudin Musa & M & 48 & Palestine \\
\hline 64 & Abir Omar Ibrahim & F & 39 & Palestine \\
\hline 65 & Ibrahim Salahudin & M & 7 & Palestine \\
\hline 66 & Muhammad Salahudin & M & 5 & Palestine \\
\hline 67 & Mussa Salahudin & M & 4 & Palestine \\
\hline 68 & Zohir Ahmad & M & 36 & Myanmar \\
\hline 69 & Niras Ahmad Samin & M & 28 & Afghanistan \\
\hline 70 & Raihana Samin & F & 23 & Afghanistan \\
\hline 71 & Arsalan Ahmad Samin & 3 & Afghanistan \\
\hline 72 & Hadis Samin & Afghanistan \\
\hline & & & \\
\hline 5 & & & \\
\hline
\end{tabular}




\subsection{Teaching and Learning Process in EFL Class}

Learning process refers to an interaction process among learners, educator and learning source in a learning environment. The definition above places subjects of learning such as learners, educator or teacher and learning source involved in a situation related each others as a unit of learning environment. The process of leaning is done by the learners as a responds toward all of learning activities programmed by the teacher.

\subsection{Approaches in Teaching and Learning Process}

An approach is a set of assumption dealing with nature of language, learning, and teaching. Method is described as an overall plan for systematic presentation of language based upon a selected approach. Technique is the specific activities manifested in the classroom that are consistent with a method and therefore are in harmony with an approach as well (Brown, 2001:14).

The first approach used in EFL class for irregular migrants is Grammar Translation approach. It is often used in EFL class in order to help studens understand the sentence patterns in English. Some of them are from the middle east, in which not from English speaking countries, but they are good enough in English conversation. However, they have weak writing skill that needs to be developed. This condition is caused by their frequency in making conversations or interactions with immigration officers or other people with English. They hardly learn writing skill as well as grammar and structure intensively at school.

Grammar translation approach is meant to help students write and make sentences correctly. The teacher then asks them to translate them to their native languages. Consequently, it helps the students to understand the sentence exactly as they do their own languages. One of the unique and also challenging things of EFL class is that the students have different native languages. For example students from Iran use persian language as mother tongue. Students from Iraq use Kurdish or Arabic language. Students from Myanmar use Myanmar language and students from Somalia use Somali or arabic language. The Grammar Translation approach make the 
students easy to understand the sentences based on their native language experience.

The second approach used in EFL class is Reading approach. In Reading approach, the teacher provides the students with a text of short story about migration or trip. After giving the text of short story, the teacher asks each student to read one sentence loudly. Then, the teacher corrects the students' pronounciation when there is a mistake. After reading the sentences in a short story, the teacher asks questions about vocabularies that they do not understand. Then the teacher explains the vocabularies with drawing picture so students understand although they have different languages.

The Reading approach is appropriate with irregular migrants because they often tell some vocabularies but they do not know how to spell them. It also directly introduces the vocabularies to the students so they are familiar with the vocabularies and sentences in English. This way will enable them to get new knowledge in reading content. With Reading approach, the students get new vocabularies without memorizing them because the students practice them in sentences. The interesting thing in Reading approach is that the teacher may ask the students after understanding the reading content and getting new vocabularie. Then, the students tell their experiences related with reading content using English combined with their native languages.

The third approach used in teaching learning process in EFL class for irregular migrants at Rumah Detensi Imigrasi is Communicative approach. It is an approach to language teaching that emphasizes class interaction by considering the means and the ultimate goal of study. The material of this approach usually is about practical usage of language such as introduction, greeting, daily conversation and other topic and vocabularies that they can practice in Rumah Detensi Imigrasi.

The approach emphasizes on the interaction between students and teacher or among students in using English. The Communicative approach is effectively used in a class as they can practice English as the target langage although they have different kinds of native language. Through direct interaction, the students are easy 
to master and practice the materials delivered with their classmate during their stay in Rumab Detensi Imigrasi. Communicative approach also serves to build closeness between students that came from different countries.

\subsection{Material Delivered in EFL Class for Irregular Migrants}

Materials are crucial points that support teaching learning process in order to reach the goals of English language teaching and learning. The material in every meeting has been structured well since the teacher prepares the lesson plan and sylabus. The books used are provided by International organization for Migration (IOM). This condition makes the teacher more prepared in delivering the materials to the students. The materials are about vocabularies, alphabet, number and counting, short story, daily conversation, and grammar.

The materials for the first level of EFL class for irregular migrants are about vocabularies, alphabet, number and counting. Such basic level of teaching materials is taught because some of them do not memorize the alphabet and English well. Vocabulary lesson is aimed to help students in daily conversation. This will bridge the students who often want to tell something but they just use gesture instead of use correct vocabularies. The vocabularies taught are related with daily activities. Counting number is also taught here. Once teacher teaches counting, the students can get the basic level of mathematics education because some of them, especially the irregular migrants from Myanmar are experiencing ethnic and religious discrimination. They are prohibited to go to school in their native country so Mathematics in EFL class can facilitate students to learn counting.

Another material is short story and daily conversation. Short story is the lesson stimulating students' vocabularies that provides new knowledge to the students. The short story helps teacher to correct students' pronunciation when reading the story. To know the level of students' understanding, the teacher gives exercise related with the content. Then teacher analyzes the students' difficulties in understanding the text. 
Conversation material is intended to help students to practice vocabularies mastered in speaking. It provides the students to get new vocabularies. Conversation lesson is so important for irregular migrants considering that their destination country use English as official language. If they can speak English fluently, it helps them to socialize with the local citizen. The short-term goal of the conversation lesson is that students can communicate with their classmates or with immigration officer in English.

The Grammar material taught is about tenses such as present tense, past tense, and future tense. The teacher teaches present tense so that students can understand the usage of sentence structure in when present time including present continuous tense and present perfect tense. It is purposed that the students can differ kinds of present time and their implication to sentence structure. Likewise, past tense is also deliverd by teacher. They are past tense, past continuous tense, and past perfect tense. In future tense, the students are taught about future time and its implication to the sentence structure.

In addition to the material, the teacher tells different kinds of sentence like verbal and nominal sentence and theirs patterns. The purpose of the Grammar material is to enable students to practice conversation and writing skill. Most of irregular migrants can not write correctly according to the rule of English. The further usage of this writing skill is to enable those irregular migrants to write for United Nations High Commissioner for Refugees (UNHCR) to get refugee status soon or to write in the magazine that IOM provides for irregular migrants in all Rumah Detensi Imigrasi in Indonesia.

\section{CONCLUSION}

EFL class in Rudenim Semarang is conducted through cooperation between Indonesian government and International organization for Migration (IOM). The teachers are from Griya ASA PKBI Kota Semarang. The purpose of this EFL class is to provide the irregular migrants a foothold in life especially English skill so can socialize and communicate especially when they got refugee status.

In teaching learning process of EFL class, the teacher use some 
approaches in teaching such as Grammar Translation, Reading, and Communicative approach. The materials delivered to the students are vocabularies, speaking, grammar and writing skill. The irregular migrants need those materials in order that they can use them in daily activities and later in the destination country. 


\section{REFERENCES}

Arikunto, Suharsimi, Prosedur Penelitian Suatu Pendekatan Praktek, Jakarta: PT Rineka Cipta, 1998.

Brown, H. Douglas, Teaching by Principles: an Interactive Approach to Language Pedagogy, New York: Pearson Education, 2001.

Indrayana, Deny, "Rudenim Overload, SOP tak Jalan", in bttp:// medanbisnisdaily.com/news/read/2013/04/06/22031/ rudenim_ overload_sop_tak_jalan/, retrieved on $08^{\text {th }}$ January 2015.

J Moleong, Lexy, Metodologi Penelitian Kualitatif, Bandung: Remadja Karya, 1989.

Krustiyati, Atik, "Kebijakan Penanganan Pengungsi Di Indonesia: Kajian Dari Konvensi Pengungsi Tahun 1951 Dan Protokol 1967”, Jurnal Law Review, (Vol.XII, No.2, November/2012)

Law No. 9 of 1992, on Immigration, chapter I, article 1, paragraph 15.

Mudjiono and Dimyati, Belajar dan Pembelajaran, Jakarta: Rineka cipta, 2009 .

Putera, Nusa, Penelitian Kualitatif: Proses dan Aplikasi, Jakarta Barat: PT Indeks, 2012.

Riyanto, Sigit, "Urgensi Legislasi Hukum Pengungsi dan Kendalanya di Indonesia”, Jurnal Hukum Internasional, (Vol. 2, No.1, Oktober/2014) 
Sjahriful, Abdullah, Memperkenalkan Hukum Keimigrasian, Jakarta: Ghalia Indonesia, 1993.

Sugiyono, Metode Penelitian Pendidikan: Pendekatan Kuantitatif, Kualitatif, dan R\&D, Bandung: Alfabeta, 2010.

Syam, M. Husni, "Perlindungan Internasional Terhadap Pengungsi dalam Konflik Bersenjata", bttp:// bukum.unisba.ac.id/syiarbukum/index.php/jurnal/jurnal-vol-xii-no2juli/item/98, retrieved on $15^{\text {th }}$ February 2015.

Syaodih Sukmadinata, Nana, Metode Penelitian Pendidikan, Bandung: PT Remaja Rosdakarya, 2010.

UNHCR, Konvensi dan Protokol Mengenai Status Pengungsi, Switzerland: UNHCR Media Relations and Public Information Service, t.t. 